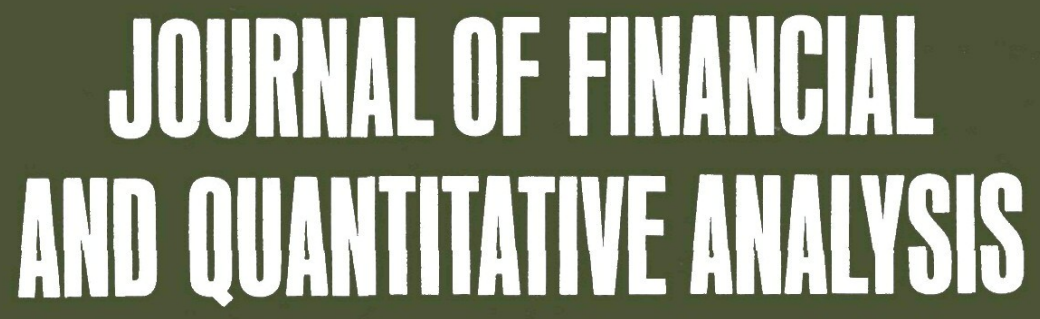

\title{
June 1979
}

C. HARVEY RORKE

On the Portfolio Effects of Nonmarketable Assets: Government Transfers and Human Capital Payments

YORAM KROLL and HAIM LEVY

Stochastic Dominance with a Riskless Asset: An Imperfect Market

PHILIP E. GRAVES

Relative Risk Aversion: Increasing or Decreasing?

S. BROWN

The Effect of Estimation Risk on Capital Market Equilibrium

TIMOTHY J. NANTELL and BARBARA PRICE

An Analytical Comparison of Variance and Semivariance Capital Market Theories

ANDREW H. CHEN

Effects of Purchasing Power Risk on Portfolio Demand for Money

FRANK MILNE

Borrowing, Short-Sales, Consumer Default, and the Creation of New Assets

JAMES BRADFIELD

A Formal Dynamic Model of Market Making

JERALD H. UDINSKY and DANIEL KIRSHNER

A Comparison of Relative Predictive Power for Financial Models of Rates of Return

JAMES A. OHLSON

Risk, Return, Security-Valuation, and the Stochastic Behavior of Accounting Numbers

RICHARD A. BERNHARD

A More General Sufficient Condition for a Unique Nonnegative Internal Rate of Return

MILES LIVINGTON

Measuring Bond Price Volatility

JACK CLARK FRANCIS and FRANK J. FABOZZI

The Effects of Changing Macroeconomic Conditions on the Parameters of the Single Index Market Model

JAMES S. ANG and JESS H. CHUA

Composite Measures for the Evaluation of Investment Performance

\section{P.D. PRAETZ}

A General Test of a Filter Effect

RICHARD W. MCENALLY and DAVID E. UPTON

A Reexamination of the Ex Post Risk-Return Tradeoff on Common Stocks

BENJAMIN BACHRACH and DAN GALAI

The Risk-Return Relationship and Stock Prices

GEORGE M. CONSTANTINIDES

A Note on the Suboptimality of Dollar-Cost Averaging as an Investment Policy 


\section{MORATORIUM}

On the advice of the JFQA Advisory Committee, a moratorium has been declared on paper submissions effective July 1, 1979, through June 30,1980. During this period no new papers will be accepted, and all manuscripts submitted for initial review will be returned immediately. This moratorium does not apply to papers submitted prior to July 1, 1979; nor will it affect publication of the Journal.

The purpose of the moratorium is to reduce the lengthy backlog of papers awaiting publication. The Committee's reasoning in support of the moratorium and other steps taken to reduce the backlog are discussed in more detail in FROM THE EDITOR in the March issue of the Journal. We recognize the severity of a moratorium, but feel strongly that the JFQA will be of greater service to its readers and its authors when publication delays are minimized. Thank you for your understanding and patience. 
A JOINT PUBLICATION

OF THE

GRADUATE SCHOOL OF BUSINESS ADMINISTRATION

UNIVERSITY OF WASHINGTON

AND THE

WESTERN FINANCE ASSOCIATION

EDITORIAL STAFF

Charles W. Haley, Managing Editor

Lynn Lewicki, Editorial Associate

University of Washington

\section{ASSOCIATE EDITORS}

Richard H. Bernhard, North Carolina State Gerald O. Bierwag, Oregon Michael J. Brennan, UBC Andrew H. Chen, Ohio State Peter A. Frost, Washington Robert S. Hamada, Chicago Frank C. Jen, SUNY, Buffalo George Kaufman, Oregon Michael A. Klein, Indiana Alan Kraus, UBC Cheng-few Lee, Illinois John G. McDonald, Stanford Richard Pettit, Houston
George E. Pinches, Kansas Barr Rosenberg, Berkeley Gary G. Schlarbaum, Purdue Clifford W. Smith, Jr., Rochester Bruno H. Solnik, CESA, Jouy-en-Josas, France Bernell K. Stone, Georgia Institute of Technology James Van Horne, Stanford David A. Walker, Federal Deposit Insurance Corporation Richard R. West, Dartmouth Robert L. Winkler, Indiana 


\section{WESTERN FINANCE ASSOCIATION}

1978-79 Executive Committee

Guilford C. Babcock, President

Donald E. Farrar, President-Elect

Keith Smith, Vice President

D. Stuart Bancroft, Secretary-Treasurer

David H. Pyle, Past President

Charles W. Haley, Editor

Thomas E. Stitzel

Peter Rose

Seha Tinic

William F. Sharpe
University of Southern California

University of Utah

University of California, Los Angeles

Pacific Lutheran University

University of California, Berkeley

University of Washington

Boise State University

Texas A\&M University

University of Alberta

Stanford University

\section{INSTITUTIONAL MEMBERS}

University of Calgary, Faculty of Business

California State College, Bakersfield

Center for Business/Economic Research

University of California, Berkeley

School of Business Administration

University of California, Los Angeles

Study Center for Finance and

Business Economics

\author{
Loyola Marymount University \\ College of Business Administration \\ University of Southern California \\ Graduate School of Business \\ Administration \\ University of Utah \\ Department of Finance
}

\section{CORPORATE SPONSORS}

Security Pacific National Bank

Wells Fargo Bank

Transamerica Corporation

Bank of America

Huntsman Chemical \& Oil Corporation

Mattel, Inc.

Gifford Fong Associates
Los Angeles, California

San Francisco, California

San Francisco, California

San Francisco, California

Salt Lake City, Utah

Hawthorne, California

Santa Monica, California

Copyright 1978 by the Graduate School of Business Administration, University of washington 
The Journal of Financial and Quantitative Analysis is published by the Graduate School of Business Administration, University of Washington, Seattle, Washington 98195, in conjunction with the Western Finance Association. Regular issues are published in March, June, September, and-December, and a Proceedings Issue is published in November. Second-class postage is paid at Seattle, Washington.

The Proceedings Issue contains selected papers, abstracts of papers, discussants' comments, and the proceedings of the Western Finance Association meetings. From time to time a special issue, devoted to one topic of interest to the membership, is published.

The views and opinions expressed are those of the authors and do not necessarily reflect those of the Graduate School of Business Administration of the University of Washington nor of the Western Finance Association.

For individuals, the annual subscription rate to the IFQA is $\$ 17.50$ (three-year rate, \$47.50); for firms or libraries, the annual rate is $\$ 25.00$ (three-year rate $\$ 70$ ). Annual subscription rates for individuals and libraries outside the United States (except Canada) are $\$ 18.50$ for individuals (three-year rate $\$ 50.50$ ), and $\$ 26.00$ for libraries and firms (three-year rate, $\$ 73$ ). Single copies are $\$ 5.00$. The fiscal year of the Journal of Financial and Quantitative Analysis begins on January 1.

Manuscripts and $\$ 25$ submission fee per manuscript ( $\$ 15$ for W.F.A. members) as well as editorial correspondence, should be sent to the Managing Editor. Correspondence relating to advertising, subscriptions, and billing should be addressed: Subscription Manager, JFQA, University of Washington, DJ-10, Seattle, WA 98195.

Correspondence pertaining to the Western Finance Association should be sent to Mr. D. Stuart Bancroft, Secretary-Treasurer, School of Business Administration, Pacific Lutheran University, Tacoma, WA 98447. 
JOURNAL OF FINANCIAL AND QUANTITATIVE ANALYSIS

University of Washington, Seattle, Washington

Vol. XIV, No. 2, June 1979

On the Portfolio Effects of Nonmarketable Assets: Government Transfers and Human Capital Payments

C. Harvey Rorke

Stochastic Dominance With a Riskless Asset: An Imperfect Market

Yoram Kroll and Haim Levy

Relative Risk Aversion: Increasing or Decreasing?

Philip E. Graves

The Effect of Estimation Risk on Capital Market Equilibrium

S. Brown

An Analytical Comparison of Variance and Semivariance Capital Market

Theories

Timothy J. Nantell and Barbara Price

Effects of Purchasing Power Risk on Portfolio Demand for Money

Andrew $H$. Chen

Borrowing, Short-Sales, Consumer Default, and the Creation of New Assets

Frank Milne

A Formal Dynamic Model of Market Making

James Bradfield

A Comparison of Relative Predictive Power for Financial Models of Rates of Return

Jerald H. Udinsky and Daniel Kirshner 
Risk, Return, Security-Valuation, and the Stochastic Behavior of Accounting Numbers

James A. Ohlson

A More General Sufficient Condition for A Unique Nonnegative Internal Rate of Return

Richard H. Bernhard

Measuring Bond Price Volatility

Miles Livingston

The Effects of Changing Macroeconomic Conditions on the Parameters of the

Single Index Market Model

Jack Clark Francis and Frank J. Fabozzi

Composite Measures for the Evaluation of Investment Performance

James S. Ang and Jess H. Chua

A General Test of a Filter Effect

P. D. Praetz

A Reexamination of the Ex Post Risk-Return Tradeoff on Common Stocks Richard W. MCEnally and David E. Upton

The Risk-Return Relationship and Stock Prices

Benjamin Bachrach and Dan Galai

A Note on the Suboptimality of Dollar-Cost Averaging as an Investment Policy George M. Constantinides 